\title{
Regional and temporal variability of melts during a Cordilleran magma pulse: Age and chemical evolution of the Jurassic arc, eastern Mojave Desert, California
}

\author{
Barth, A.P. ${ }^{1}$, Wooden, J.L. ${ }^{2}$, Miller, D.M. ${ }^{3}$, Howard, K.A. ${ }^{3}$, Fox, L.K. ${ }^{4}$, Schermer, \\ E.R. ${ }^{5}$, and Jacobson, C.E. ${ }^{6}$ \\ ${ }^{1}$ Department of Earth Sciences, Indiana University Purdue University Indianapolis, \\ Indianapolis, IN 46202 \\ ${ }^{2}$ U.S. Geological Survey and Stanford University (retired) \\ ${ }^{3}$ U.S. Geological Survey, Menlo Park, CA 94025 \\ ${ }^{4}$ Department of Geological and Environmental Sciences, University of the Pacific, \\ Stockton, CA 95211 \\ ${ }^{5}$ Department of Geology, Western Washington University, Bellingham, WA 98225 \\ ${ }^{6}$ Department of Geological and Atmospheric Sciences, Iowa State University, Ames, IA \\ 50011 and Department of Geology and Astronomy, West Chester University, West \\ Chester, PA 19383
}

\section{ABSTRACT}

Intrusive rock sequences in the central and east Mojave Desert segment of the Jurassic Cordilleran arc of the western US record regional and temporal variations in magmas generated during the second prominent pulse of Mesozoic continental arc magmatism. $\mathrm{U} / \mathrm{Pb}$ zircon ages provide temporal control for describing variations in rock and zircon geochemistry that reflect differences in magma source components. These source signatures are discernible through mixing and fractionation processes associated with magma ascent and emplacement. The oldest well-dated Jurassic rocks defining initiation of the Jurassic pulse are a 183 Ma monzodiorite and a 181 Ma ignimbrite. Early to Middle Jurassic intrusive rocks comprising the main stage of magmatism include two high K calc-alkalic groups; to the north, the deformed 183 to 172 Ma Fort 
Irwin sequence and contemporaneous rocks in the Granite and Clipper Mountains, and to the south the 167 to 164 Ma Bullion sequence. A Late Jurassic suite of shoshonitic, alkali-calcic intrusive rocks, the Bristol Mountains sequence, ranges in age from 164 to $161 \mathrm{Ma}$ and was emplaced as the pulse began to wane. Whole rock and zircon trace element geochemistry define a compositionally coherent Jurassic arc with regional and secular variations in melt compositions. The arc evolved through the magma pulse by progressively greater input of old cratonic crust and lithospheric mantle into the arc magma system, synchronous with progressive regional crustal thickening.

\section{INTRODUCTION}

The latest Paleozoic to Mesozoic Cordilleran magmatic arc in the western US formed as a consequence of prolonged east-directed subduction initiated in Permo-Triassic time (Saleeby and Busby-Spera, 1992; Miller et al., 1995; Barth and Wooden, 2006; Saleeby, 2011; Barth et al., 2011, 2012). The first magmatic pulse in the arc was widespread, but both the exposed and detrital records of arc magmatism indicate that the second, Jurassic magmatic pulse was geochemically distinct and of significantly larger volume (Barth et al., 2013). The tectonic and magmatic causes of the initiation and evolution of the Jurassic magmatic pulse are therefore a key to understanding the non-steady state behavior of the US Cordilleran arc. Improved geochronology and geochemistry of a region-wide set of Jurassic igneous rocks is needed to better reconstruct Jurassic magmatic events that remain incompletely understood due to isolated exposures of the arc and the generally imprecise dating of Jurassic rocks (Walker et al., 2002; Haxel and Miller, 2007). 
Uncertainties in timing of magmatism also translate into uncertainties in the relationship of arc magmatic pulses to tectonic evolution of the plate margin. In the specific case of the Jurassic arc, the timing of magmatism relative to intra-arc shortening and/or extension remains uncertain, as is the relationship between the arc and continental interior stratigraphic records, especially eolian sand sheets (Busby-Spera, 1988; Walker et al., 1990; Dunne et al., 1998; Dunne and Walker, 2004; Haxel and Miller, 2007). The exposed parts of the Jurassic arc in the Mojave Desert (Figure 1) record evidence of both extensional and contractile deformation that was broadly synchronous with magmatism, but it is unclear if this evidence indicates alternation of deformational style with time or with position in the arc infrastructure (Walker et al., 2002; Busby et al., 2002). Extensional structures may reflect upper crustal extension associated with caldera development, or perhaps an elongate arc-graben depression (Busby-Spera, 1988; Saleeby and Busby-Spera, 1992; Schermer, 1993; Busby et al., 2002). Contractile structures developed locally in concert with magmatism and may record a regional arc-fringing to intra-arc thrust belt reflecting arc-parallel contraction at relatively deeper structural levels (Walker et al., 1990; Dunne et al., 1998; Walker et al., 2002; Dunne and Walker, 2004).

Precise geochronologic data for arc volcanic and plutonic rocks are fundamental to understanding the secular and tectonic evolution of the early Cordilleran arc. Existing regional data from the western US make it clear that volcanism was spatially associated with emplacement of plutonic rocks (Schermer and Busby, 1994; Schermer et al., 2002; Dunne et al., 1998; Busby et al., 2002; Fohey-Breting et al., 2010), yet limited geochronologic and geochemical data for older plutons hampers our understanding of 
the long-term petrologic evolution of the arc system. In this study we extend the earlier work of Fox and Miller (1990), Miller and Glazner (1995), Gerber et al. (1995), Howard et al. (1995), and Schermer et al. (2001) by reporting SIMS (secondary ion mass spectrometry) single zircon ages for plutonic rocks in the central and east Mojave Desert segment of the Jurassic arc. SIMS analysis can yield precise crystallization ages for older arc plutonic rocks that were difficult or impossible to adequately date by conventional TIMS (thermal ionization mass spectrometry) analysis of bulk zircon fractions with inheritance, $\mathrm{Pb}$ loss, or a combination of these complicating effects (Barth and Wooden, 2006). New SIMS age data provide a framework for understanding both regional and secular variations in early plutonism in this arc segment constructed across the North American craton edge.

\section{GEOLOGIC SETTING}

\section{Regional Geochronology of the Jurassic Magmatic Arc in the Southwest US}

A compilation of available reliable geochronologic data (Figure 2), primarily U-Pb zircon ages, suggests both regional and secular variations in the timing of Jurassic arc magmatism, and may also shed light on arc tectonic evolution. The largest number of precise zircon ages of plutonic rocks is available from the southern Mojave Desert and Transverse Ranges, where the Jurassic arc has been divided into older inboard and younger outboard parts (Barth et al., 2008). Although it is misleading to view this compilation of ages as equivalent to magma volumes, the data do indicate regionally widespread magmatism in Middle to Late Jurassic time, between about 166 and 150 Ma. In contrast to this existing plutonic age record, comparative age histograms for detrital zircons in intra-arc and retroarc basins suggest that the most voluminous 
magmatism in the inboard part of the arc was in Early to early Late Jurassic time, between about 185 and 160 Ma. Relatively distal age records of arc magmatism are also available from forearc detrital zircons and from the depositional ages of ash beds in the continental interior. Zircons in forearc sediments are relatively equally distributed across Middle to mid-Late Jurassic time. Ash beds show a broadly similar age distribution, with a Late Jurassic peak (Morrison Formation) similar in age to plutons that are most common in the outboard part of the arc in the Transverse Ranges, and a Middle Jurassic peak (Carmel Formation and Page Sandstone) which is in close agreement with the age peak in the retroarc detrital zircon histogram. Dickinson and Gehrels (2010) compiled detrital zircons from younger continental interior sediments that also suggest voluminous magmatism in the arc in Early to Middle Jurassic time.

Existing precise geochronologic data summarized in Figure 2 thus indicate significant magmatism in both Middle and Late Jurassic time, with Middle Jurassic magmatism dominant in a relatively inboard position in the arc. However, such inboard Middle Jurassic magmatism is not yet well defined by precise zircon ages in bedrock of the arc itself. In this study we present trace element and isotopic data for zircons from twenty samples, of which fourteen yielded precise crystallization ages for plutonic rocks in the inboard part of the Jurassic arc in the eastern Mojave Desert. The new ages for these plutons are synchronous with peaks in the retroarc and continental interior geochronologic records and thus provide a more complete picture of the timing of initiation of the second, Jurassic magma pulse of the Cordilleran continental margin arc and the regional petrogenetic character of voluminous Jurassic arc plutonism.

\section{Plutonism in the East Mojave Desert}


Mesozoic plutons in the central and east Mojave Desert (henceforth 'east Mojave') were emplaced into two fundamentally distinct bedrock types. In the northern east Mojave plutons were emplaced into Paleozoic metasedimentary strata of eugeoclinal affinity, whereas further to the south and east plutons were emplaced into Neoproterozoic and Paleozoic miogeoclinal-cratonal strata and their Paleoproterozoic gneissic substrate constituting the old Laurentian craton edge (e.g. Stewart and Poole, 1975; Stone and Stevens, 1988; Martin and Walker, 1992; Walker et al., 2002). The region of juxtaposition of eugeoclinal and miogeoclinal-cratonal strata marks a fundamental crustal structural boundary initially formed in Pennsylvanian-Permian time and repeatedly reactivated, and also represents a fundamental change in lithosphere type, from young oceanic to Laurentian Proterozoic continental lithosphere.

Jurassic plutonic rocks are widely exposed in the east Mojave and Transverse Ranges (Fox and Miller, 1990; Howard, 2002; Haxel and Miller, 2007), forming the link between Jurassic arc segments in the Sierra Nevada of central California and the Sonoran Desert region of southern California, Arizona and northern Sonora. In the northern east Mojave, the Fort Irwin sequence is composed of foliated diorite, quartz monzodiorite and granite that intruded along and outboard of the North American craton edge (Schermer et al., 2001). Compositionally similar foliated metaplutonic rocks with Middle Jurassic or older ages are exposed (1) to the south at Alvord Mountain and in the Cronese Hills (Miller et al., 1995; Walker et al., 1990); (2) in the Granite Mountains, where Howard et al. (1987; Young et al., 1992) described a foliated plutonic suite, intruded by relatively little-deformed diorite, quartz monzonite and granite; (3) in the 
Clipper Mountains, where Howard et al. (1995; Gerber et al., 1995) described the Goldhammer pluton emplaced synchronous with intra-arc thrusting.

To the south, within the North American craton, Howard (2002; Mayo et al., 1998 and Howard et al., 2013a, b) described the Jurassic Bullion Mountains Intrusive Suite (Figure 1), comprising diorite, quartz monzodiorite, quartz monzonite and granite. Rocks of this intrusive suite are deformed only along the eastern side, where they are incorporated into the Late Cretaceous Sevier - Old Woman - Maria fold and thrust belt (Miller et al., 1982; Foster et al., 1992). Zircon ages reported by Barth et al. (2008) and in this study indicate that this intrusive suite is Middle Jurassic in age but younger than the foliated Fort Irwin sequence and related rocks in the Granite and Clipper Mountains to the north.

Spatially between the Fort Irwin sequence and the Bullion Mountains Intrusive Suite, Fox and Miller (1990) described the Bristol Mountains sequence, comprising subalkaline diorite and monzodiorite, metaluminous to weakly peraluminous granite, and mixed plutonic rocks exposed in the Lava Hills, Bristol Mountains, and the south Providence Mountains and adjacent Colton Hills (Figure 1). These authors summarized available KAr minimum ages of 159 to $139 \mathrm{Ma}$, and unpublished U-Pb zircon ages of 164 to 162 Ma (Stacy, written communication in Fox and Miller, 1990) indicating a Jurassic age for this sequence. In this study we report SIMS zircon ages indicating the Bristol Mountains sequence constitutes the youngest of the three main intrusive rock sequences in the Early to early Late Jurassic arc of the east Mojave. Waning arc magmatism is marked by volcanism and latest Jurassic plutons and dikes intruded between about 154 and 149 Ma. 


\section{ANALYTICAL METHODS}

Zircons were separated from whole rock samples by gravimetric techniques, mounted in epoxy and polished for examination using a cathodoluminescence detector on a scanning electron microscope. Cathodoluminescence images were used to guide selection of analysis points. Uranium, Th and $\mathrm{Pb}$ concentrations and isotopic ratios were measured by SIMS using the U.S. Geological Survey SHRIMP-RG (sensitive highresolution ion microprobe-reverse geometry) ion microprobe at Stanford University. Zircons were ablated using a $\sim 30 \mu \mathrm{m}$ diameter, 5 to $6 \mathrm{nA} \mathrm{O}_{2}^{-}$primary beam. Isotopic ratios were standardized against Braintree Complex zircon R33 (419 Ma; Black et al., 2004). Errors on measured ages of spots within individual grains were calculated with Squid (Ludwig, 2001) and are reported at one sigma. Crystallization ages of rocks were calculated with Isoplot (Ludwig, 2012) and are reported with associated uncertainties at the 95\% confidence level (Table 1). All geochronology sample locations and zircon spot analyses are archived in the EarthChem Geochron database (http://www.geochron.org/search.php).

The data set for this study includes whole rock major and trace element analyses of samples from the Fort Irwin, Bristol Mountains and Bullion sequences completed at the U.S. Geological Survey, Macquarie University and Michigan State University (Table DR1). Major oxides and most trace element abundances were measured by $\mathrm{x}$-ray fluorescence, and $U$, Th and REE were measured by instrumental neutron activation at the U.S. Geological Survey, following the method of Baedecker and McKown (1987). Techniques for whole rock analyses at Macquarie University were described by Todd et al. (2003) and at Michigan State University by Barth et al. (2011). 
Trace element concentrations in zircons were measured in the same volume sputtered for $\mathrm{U}, \mathrm{Th}$, and $\mathrm{Pb}$ isotopic measurements (Table DR2). Count rates for $\mathrm{Hf}, \mathrm{Y}$ and rare earth elements (REE) were measured at the beginning of each magnet cycle. Count rates were normalized to ${ }^{90} \mathrm{Zr}_{2} \mathrm{O}$, and concentrations were standardized against Madagascar Green (MAD) zircon (Barth and Wooden, 2010). Trace element analyses were reduced utilizing a combined set of MAD analyses from multiple analytical sessions in order to provide a robust long-term average. These Th and $\mathrm{U}$ concentrations are therefore not identical to those calculated from single geochronologic analytical sessions using Squid, but are typically within 3-6\% for both $U$ and Th. Precision for most other trace elements ranges from 3 to $5 \%$, but up to $16 \%$ for some light rare earth elements at low concentrations.

\section{ZIRCON U-PB GEOCHRONOLOGY}

\section{Fort Irwin Sequence}

In order to determine intrusive relations for the Fort Irwin sequence, we dated six samples in and immediately to the west of the Tiefort Mountains, and one sample from Granite Pass in northern Fort Irwin. In the Tiefort Mountains, Schermer et al. (2001) described the South Tiefort orthogneiss as a variably deformed intrusive complex composed of diorite, equigranular to porphyritic quartz monzodiorite to granodiorite, and foliated granite. Samples of the diorite gneiss and equigranular granodiorite gneiss yielded conventional TIMS zircon minimum ages of 164 and $160 \mathrm{Ma}$, with evidence for both minor inheritance and post-crystallization $\mathrm{Pb}$ loss; the authors pointed out that older crystallization ages for the protolith intrusive sequence are possible because of the uncertain magnitude of $\mathrm{Pb}$ loss. This inference is supported by an older TIMS zircon 
age of $179 \mathrm{Ma}$ for diorite gneiss $10 \mathrm{~km}$ to the south at Alvord Mountain (Miller et al., 1995). Deformation of the intrusive sequence is bracketed by a minimum age provided by a $148 \pm 14$ Ma felsic Independence dike. The South Tiefort orthogneiss and the Tiefort Mountain Granite, tentatively assigned a Late Jurassic age, are intruded by the $\sim 148$ Ma dike swarm and by unnamed coarse-grained equigranular to porphyritic granites tentatively assigned a Late Cretaceous age (Schermer et al., 2001).

New SIMS ages (Table 1 and Figure 3) confirm an older age for the Jurassic Fort Irwin sequence including rocks of the South Tiefort orthogneiss. Three samples from the Fort Irwin area best define the age of the sequence. Foliated monzodiorite (sample JW255) yielded mostly concordant spot ages, and excluding one grain with higher ${ }^{207} \mathrm{~Pb} /{ }^{206} \mathrm{~Pb}$, eleven grains yield a weighted mean ${ }^{206} \mathrm{~Pb} / 238 \mathrm{U}$ age of $183 \pm 2 \mathrm{Ma}$. This is the oldest age yet obtained from the sequence, but two additional samples collected a few kilometers to the southwest of JW255 support an Early Jurassic age for this sequence. Quartz monzodiorite (sample Fl77) yielded fourteen concordant spot analyses; excluding two significantly younger grains we obtain a weighted mean ${ }^{206} \mathrm{~Pb} * 238 \mathrm{U}$ age of 172 \pm 1 Ma. A nearby second quartz monzodiorite sample (sample JW250) yielded a concordant set of eight spot analyses with a weighted mean ${ }^{206} \mathrm{~Pb} * / 238 \mathrm{U}$ age of $174 \pm 1$ Ma. These three samples allow us to infer that the Fort Irwin sequence was emplaced in late Early to early Middle Jurassic time, between 183 and 172 Ma. Two samples of deformed granitic rocks further east in the range show greater effects of $\mathrm{Pb}$ loss, but are consistent with this age assignment. A foliated quartz monzodiorite (sample JW266) yielded nine grains with a range of concordant to slightly discordant ages consistent with variable loss of radiogenic $\mathrm{Pb}$; the oldest group of four grains form a coherent 
group with a weighted mean ${ }^{206} \mathrm{~Pb}^{\star / 238} \mathrm{U}$ age of $175 \pm 2 \mathrm{Ma}$, which we takes as a minimum age that may closely approximate the crystallization age of this rock. A foliated granodiorite (sample JW265) collected further east, a few hundred meters west of the South Tiefort shear zone, is also disturbed; ten grains did not yield a single population, but the oldest group of grains suggests a minimum crystallization age of $168 \mathrm{Ma}$. A texturally similar granodiorite (sample 9NS) from the Cave Mountain area to the south, adjacent to the Cronese Hills, is more disturbed; fifteen grains did not yield a single population, suggesting a minimum crystallization age of $\sim 155 \mathrm{Ma}$, but the oldest grains suggest this rock may be as old as, or older than, $165 \mathrm{Ma}$.

At the east end of South Tiefort Mountain, the Tiefort Mountain Granite intrudes the 183 to 172 Ma Fort Irwin sequence. We analyzed nine grains from a sample (JW267) of this unit, but they did not yield a single population, indicating only a minimum age of $162 \mathrm{Ma}$. This granite locally truncates mylonitic foliation and thus provides an estimate of 172 to $162 \mathrm{Ma}$ for the timing of the principal deformation of the Fort Irwin sequence. This deformation age bracket is consistent with the $>148 \mathrm{Ma}$ age for deformation suggested by Schermer et al. (2001) and in a broader regional sense is consistent with the 169 to 154 Ma timing for deformation correlated with regional intra-arc thrusting in the East Sierran thrust system (Walker et al., 1990; Dunne and Walker, 2004).

To the east and northeast, the Jurassic Fort Irwin sequence was intruded by coarsegrained, equigranular to porphyritic granite that extends northward from eastern Tiefort Mountain. A granite from Granite Pass (sample JW268) yielded nine grains with a range of concordant to slightly discordant ages consistent with both inheritance and loss of 
radiogenic $\mathrm{Pb}$; a coherent group of six grains yielded a weighted mean ${ }^{206} \mathrm{~Pb} / 238 \mathrm{U}$ age of $76 \pm 1 \mathrm{Ma}$, which we takes as closely approximating the crystallization age of this rock.

\section{Regional Extent of Deformed Intrusive Rock Sequences}

In order to test the regional extent of Jurassic deformed intrusive rocks potentially correlative with the Fort Irwin sequence, we analyzed zircons from three additional deformed plutonic rocks (Table 1 and Figure 4) for which TIMS analyses had suggested Jurassic crystallization ages. Nine zircons obtained from a gneissic quartz monzodiorite (sample GM204) in Bull Canyon in the Granite Mountains southeast of Fort Irwin (Howard et al., 1987; note that there are four 'Granite Mountains' in the Mojave Desert the Bull Canyon locality is labeled in Figure 1) are concordant to very slightly discordant and spread along concordia in excess of what is expected due solely to analytical errors. The oldest group of five concordant grains yielded a weighted mean ${ }^{206} \mathrm{~Pb}^{\star / 238} \mathrm{U}$ age of $\sim 172 \mathrm{Ma}$, which we take to indicate the minimum crystallization age for the Jurassic intrusive sequence in this range. This age is consistent with field relationships indicating the foliated unit is intruded by diorite that yielded a conventional TIMS zircon age of $\sim 155 \mathrm{Ma}$ (Young et al., 1992), and suggests the older deformed intrusive sequence in the Granite Mountains is contemporaneous with the foliated Fort Irwin sequence.

Twenty-five km farther east in the east Mojave, a foliated plutonic suite in the Clipper Mountains includes sheeted diorite and granodiorite of the Goldhammer pluton, and diorite of the Chuckwalla Springs pluton (Howard et al., 1995; Gerber et al., 1995). We reanalyzed zircons from the granodiorite (sample ND40) described by Howard et al. (1995) from the Goldhammer pluton, for which TIMS analysis yielded a highly 
discordant lower intercept age of $161 \pm 10 \mathrm{Ma}$. The zircons in this sample are unusually complex, with abundant premagmatic cores and magmatic overgrowths. We analyzed thirteen magmatic domains and overgrowths that are concordant but spread along Concordia in excess of analytical errors. Excluding the distinctly younger analyses and

one analysis with high ${ }^{207} \mathrm{~Pb} /{ }^{206} \mathrm{~Pb}$, nine zircons yielded a weighted mean ${ }^{206} \mathrm{~Pb} b^{\star 238} \mathrm{U}$ age of $176 \pm 2 \mathrm{Ma}$. We take this age to be the best estimate of the emplacement age of the Goldhammer pluton; while this age is significantly older than the TIMS lower intercept age, it is consistent with a 175 to $180 \mathrm{Ma}$ hornblende ${ }^{40} \mathrm{Ar} /{ }^{39} \mathrm{Ar}$ minimum age for this pluton (Foster et al., 1990; Howard et al., 1995).

\section{Bristol Mountains Sequence}

In several ranges in the northern and eastern Mojave Desert, relatively little-deformed granitoid rocks intrude this deformed Early to Middle Jurassic intrusive terrane. In the Fort Irwin area post-kinematic granite with a minimum age of $162 \mathrm{Ma}$ intruded the orthogneisses of the Fort Irwin sequence, as originally inferred by Schermer et al. (2001). Further south, Walker et al. (1990) showed that granite intruded foliated gabbro, monzonite and granite at about $155 \mathrm{Ma}$ in the Cronese Hills. In order to determine if similar intrusive age relations extend further south and east, we dated six samples from the Bristol Mountains and from the Colton Hills adjacent to the Providence Mountains.

In the Bristol Mountains, Fox and Miller (1990) described the Bristol Mountains sequence as a texturally heterogeneous mafic to felsic intrusive complex, which based on alteration styles and association with hypabyssal and metavolcanic rocks of similar age was probably emplaced at upper crustal levels. The sequence was tentatively 
assigned a Jurassic age based on 159-139 Ma K-Ar cooling ages and unpublished U$\mathrm{Pb}$ zircon ages of 164 to $162 \mathrm{Ma}$.

SIMS ages (Table 1, Figures 5 and 6) suggest that the Bristol Mountains sequence is mostly early Late Jurassic in age and younger than the Early to Middle Jurassic Fort Irwin sequence. Three samples of intermediate bulk composition best establish the age of the sequence. Quartz monzonite (sample BR34) from the southern end of the Bristol Mountains yielded mostly concordant spot ages, and excluding two grains with high ${ }^{207} \mathrm{~Pb} /{ }^{206} \mathrm{~Pb}$, ten grains yield a weighted mean ${ }^{206} \mathrm{~Pb}^{\star} / 238 \mathrm{U}$ age of $164 \pm 2 \mathrm{Ma}$. This is the oldest age yet obtained from the sequence. Porphyritic quartz monzodiorite (09757) from the Lava Hills along the southwestern side of the range yielded a single population with a mean ${ }^{206} \mathrm{~Pb}^{\star} / 238 \mathrm{U}$ age of $161 \pm 2 \mathrm{Ma}$. A quartz syenite collected a few kilometers to the northwest of BR34 (sample BR44) yielded fourteen concordant to very slightly discordant spot analyses and a weighted mean ${ }^{206} \mathrm{~Pb} / / 238 \mathrm{U}$ age of $162 \pm 2 \mathrm{Ma}$. A diorite (sample BR94) from the Orange Blossom mine area yielded a range of concordant and discordant zircons, which indicate an minimum crystallization age of $\sim 161 \mathrm{Ma}$. Fox and Miller (1990) correlated heterogeneous intrusive rocks in the southern Providence Mountains and adjacent Colton Hills with the intrusive sequence in the Bristol Mountains. We analyzed a granodiorite (sample $\mathrm{CH} 115$ ) from the central Colton Hills, which yielded thirteen concordant to very slightly discordant spot ages and a weighted mean ${ }^{206} \mathrm{~Pb}^{\star} / 238 \mathrm{U}$ age of $161 \pm 2 \mathrm{Ma}$ that supports this correlation.

\section{Bullion Sequence}

In the Bullion, Sheep Hole, and eastern Pinto Mountains, the Bullion Mountains Intrusive Suite of Howard (2002) is composed of the porphyritic Virginia Dale Quartz 
Monzonite and equigranular to porphyritic rocks ranging in composition from quartz monzodiorite to granite. Quartz diorite and diorite are commonly spatially associated with this suite. The Virginia Dale Quartz Monzonite is also locally associated with texturally and compositionally similar hypabyssal and metavolcanic rocks suggesting that much of this sequence, like the Bristol Mountains sequence, was emplaced at upper crustal levels. We group these rocks informally as the Bullion sequence, including some more deeply exhumed plutons to the southwest of the same age. The sequence was assigned a late Middle Jurassic age based on U-Pb zircon ages of 165 to $167 \mathrm{Ma}$ from the eastern Transverse Ranges (Barth et al., 2008).

SIMS ages (Table 1 and Figure 7) confirm the late Middle Jurassic age and the regional extent of the Bullion sequence from the Kilbeck Hills on the east, to Valley Mountain on the west, and to the Eagle Mountains on the south. The quartz diorite of the Kilbeck Hills (sample ND52) yielded twelve concordant analyses, with two slightly older grains and a coherent younger group of ten grains which yielded a weighted mean ${ }^{206} \mathrm{~Pb}^{\star} / 238 \mathrm{U}$ age of $166 \pm 2 \mathrm{Ma}$, which we take to be the best estimate of the crystallization age of this unit. The quartz diorite is intruded by foliated porphyritic granodiorite and granite of the Chubbuck Porphyry (sample ND53) and by the granite gneiss of Kilbeck Hills (sample ND 51; Howard, 2002). Both of these units yielded a range of concordant ages suggestive of minor $\mathrm{Pb}$ loss, and both samples yielded concordant main groups of grains with identical weighted mean ${ }^{206} \mathrm{~Pb} * 238 \mathrm{U}$ ages of $165 \pm 2$ and $165 \pm 3 \mathrm{Ma}$, consistent with field relationships. A sample of the Virginia Dale Quartz Monzonite (sample 09759) exposed at Valley Mountain yielded 12 concordant spot analyses which give a weighted mean ${ }^{206} \mathrm{~Pb}^{\star} / 238 \mathrm{U}$ age of $164 \pm 2 \mathrm{Ma}$, which overlaps with the $167 \pm 1 \mathrm{Ma}$ 
age reported by Barth et al. (2008) for this unit in the Pinto Mountains immediately to the south. A similar porphyritic quartz monzodiorite from the Eagle Mountains (sample EM) yielded 13 concordant grains with a weighted mean ${ }^{206} \mathrm{~Pb} \star / 238 \mathrm{U}$ age of $165 \pm 2 \mathrm{Ma}$. Rocks of the Bullion Mountains Intrusive Suite are intruded by units of the Cadiz Valley Batholith (John, 1981; Calzia, 1982; Howard, 2002), dated at 77 to $73 \mathrm{Ma}$ (Barth et al., 2004; Economos et al., 2010).

\section{WHOLE ROCK GEOCHEMISTRY}

Geochemical data for whole rock samples indicate regional and secular variations in magma compositions among intrusive rocks in the east Mojave segment of the Jurassic arc (Figure 8). The Fort Irwin sequence (183-172 Ma) and Bullion sequence (167-164 $\mathrm{Ma}$ ) are compositionally very similar, ranging continuously from 50 to $76 \% \mathrm{SiO}_{2}$. Both define high $\mathrm{K}$ calc-alkalic rock suites, in the sense of having Peacock indices of 56-59 and lacking significant Fe enrichment (Peacock, 1931; Miyashiro, 1974; Arculus, 2003). Both sequences are also uniformly light REE-enriched and depleted in high field strength elements (HFSE), with Zr contents that rise to a maximum of about $300 \mathrm{ppm}$ at $-60-65 \% \mathrm{SiO}_{2}$ and fall at higher whole rock silica contents (Figure 9). In contrast, the Late Jurassic Bristol Mountains sequence (164-161 Ma) is shoshonitic, alkali-calcic, and has high $\mathrm{Ba}, \mathrm{Rb}$ and Fe/Mg in comparison to the older calc-alkalic sequences (Figure 8; Fox and Miller, 1990). The Bristol Mountains sequence is distinctly enriched in total REE and HFSE in comparison to the Fort Irwin and Bullion sequences, with maximum $\mathrm{Zr}$ contents of $\sim 700-1000 \mathrm{ppm}$ at $65 \% \mathrm{SiO}_{2}$ (Figure 9 ). This younger alkali-calcic sequence is light REE-enriched compared to the calc-alkalic sequences, with average whole-rock Nd/Yb about $40 \%$ higher at intermediate silica contents. The relatively high 
$\mathrm{Fe}, \mathrm{Zr}, \mathrm{Y}$, and $\mathrm{Nb}$ abundances and high $\mathrm{Ga} / \mathrm{Al}$ in the Bristol sequence are intermediate in values between typical arc or "I-type" granitic rocks and ferroan "A-type" granitic rocks (Whalen et al., 1997).

\section{ZIRCON TRACE ELEMENT GEOCHEMISTRY}

Elemental analyses completed during zircon geochronologic analyses provide an independent estimate of the trace element compositions of melts that formed these Jurassic sequences. Zircons are compositionally heterogeneous, both within individual grains and between grains in a given sample. Here we consider the average and ranges of zircon trace element compositions in intrusive rocks as an indicator of similarities and differences in average melt compositions. Compositions considered here are based on zircon spot analyses that were included in calculation of weighted mean $\mathrm{Pb} / \mathrm{U}$ crystallization ages, about $65 \%$ of all zircon analyses. An additional $5 \%$ of analyses with anomalously high light REE abundances were excluded as the analyzed zircon volumes likely contained light REE-enriched apatite inclusions.

Uranium and thorium abundances in magmatic zircons record geochemical differences between melts of the three sequences. Concentrations of these elements in magmatic zircons from the older, high $\mathrm{K}$ calc-alkalic Fort Irwin sequence vary over an order of magnitude across the bulk compositional range from monzodiorite to granite, but exhibit consistently low average Th/U ( $\leq 1$; Figure 10$)$. In comparison, samples from the high $\mathrm{K}$ calc-alkalic Bullion sequence intruded to the south have zircons with similar average $U$ concentrations but higher Th/U values up to $\sim 2.5$. Zircons from the youngest, alkalicalcic Bristol Mountains sequence are distinctive in having low $U$ concentrations and $\mathrm{Th} / \mathrm{U}=1$-3. Zircon Th/U thus reflects both a regional difference between the high $\mathrm{K}$ calc- 
alkalic sequences, with higher Th/U in zircons from Middle Jurassic intrusive rocks inboard of the craton edge, and temporal differences, in the low $U$ concentrations and high Th/U characterizing the youngest, LIL-enriched Bristol Mountains sequence.

Regional and temporal differences in Th/ $\mathrm{U}$ correlate with other zircon trace element abundances and these differences are discernible despite fractionation-induced variability of coexisting grains within individual rock samples. Hafnium solid solution in zircon serves as a monitor of melt fractionation (Anderson et al., 2008; Barth and Wooden, 2010; Claiborne et al., 2010). Zircons from each of the three sequences exhibit comparable ranges in $\mathrm{Hf}$ concentrations, reflecting similar ranges of melt fractionation and internal trends typical of intrusive rocks (Figure 11), with higher $\mathrm{Hf}$ abundances reflecting evolution toward more fractionated, lower temperature melts. Average $\mathrm{Hf}$ concentrations are lower in zircons from the Bristol Mountains sequence; because the Bristol Mountains and Fort Irwin sequences have similar, relatively unfractionated whole rock $\mathrm{Hf} / \mathrm{Zr} \sim 0.03$, this likely reflects higher melt $\mathrm{Zr}$ concentrations and earlier zircon saturation. $U$ and Th both increase in abundance with increasing $\mathrm{Hf}$, and $\mathrm{Th} / \mathrm{U}$ decreases. Zircons are enriched in middle and heavy REE, and higher $\mathrm{Hf}$ zircon domains are usually associated with higher heavy REE abundances, higher $\mathrm{Yb} / \mathrm{Gd}$ and more negative Eu anomalies, consistent with the observation that higher Hf zircon crystallized from fractionated, low Th/U melts.

Differences in melt composition between the calc-alkalic and LIL-enriched alkali-calcic intrusive sequences are also apparent in the extent of uranium depletion and rare earth element fractionation (Figure 12). The older, high $\mathrm{K}$ calc-alkalic Fort Irwin and Bullion sequence zircons have consistently higher $\mathrm{U} / \mathrm{Yb}$ and lower $\mathrm{Ce} / \mathrm{Yb}$ and $\mathrm{Gd} / \mathrm{Yb}$ than 
zircons from the youngest, alkali-calcic Bristol Mountains sequence. Thus, rare earth element ratios and Th/U in zircon solid solutions serve to distinguish melts from Jurassic intrusive suites in a manner that is complementary to differences in magmatic REE abundances estimated from whole rocks (Figure 9). Zircons from the Fort Irwin and Bullion sequences have similar REE abundances and fractionation despite the higher Th/U in the Bullion sequence, whereas higher Th/U zircons in the LIL-enriched, uranium-depleted Bristol Mountains sequence are characterized by further relative enrichment in LREE.

\section{DISCUSSION}

Zircon geochronologic data and the chemistry of rocks and zircons underscore similarities and differences among three voluminous intrusive sequences recording a pulse of Jurassic magmatism across the Mojave Desert region of California.

Widespread older calc-alkalic sequences were intruded by a younger alkali-calcic intrusive sequence. Integration of zircon and whole rock geochemical data from intrusive rocks allows us to infer changes in average melt compositions at a regional scale; we suggest that these changes, considered in context of age relationships, indicate an important role for crustal thickening in an evolving arc magma pulse.

The long-term Mesozoic evolution of the California arc was characterized by steadystate magmatism and three shorter-duration high-flux magmatic episodes (pulses or flare-ups; Bateman, 1992; Ducea and Barton, 2007; Barth et al., 2013; de Silva et al., 2015). Arc magmatism during the second, Jurassic pulse in the California arc is best recorded by plutonic sequences, but includes widely separated small remnants of a silicic ignimbrite cover sequence. Jurassic intrusive and extrusive rock sequences thus 
may provide key insights into the plutonic underpinnings of volcano-plutonic complexes recording an arc magma pulse (Saleeby et al., 1990; Fohey-Breting et al., 2010). The segment of the California arc in the Mojave Desert and Transverse Ranges provides a significant exposure of rocks formed during the Jurassic magma pulse. Intrusive sequences and remnants of volcanic cover here stretch across a $2 \times 3$ degree area $(\sim 200 \times 300 \mathrm{~km})$, and are therefore of comparable spatial extent to volcano-plutonic complexes recording ignimbrite flare-up in the modern Andean continental arc (e.g. de Silva, 1989; de Silva and Gosnold, 2007).

New and existing geochronologic data indicate a primary Jurassic plutonic and volcanic pulse of $\sim 35-40$ m.y. duration, waxing in the Early Jurassic, and stretching into the Late Jurassic as waning magmatism migrated westward toward the former fore-arc region (Figures 1 and 13). The Jurassic magma pulse evolved across a structural boundary in the arc framework, separating a continental arc in the southern Mojave and Transverse Ranges from the continent-fringing arc in the northeast Mojave that extends to the north into the Sierra Nevada. Plutonism commenced in Early Jurassic time, about $183 \mathrm{Ma}$, and the main stage persisted through Middle and early Late Jurassic time, until about 161 Ma when waning and westward arc migration commenced. The waxing and main stages of the intrusive pulse are recorded by high $\mathrm{K}$ calc-alkalic intrusive sequences both north and south of the craton edge. The older, Early to early Middle Jurassic calcalkalic suite, the Fort Irwin sequence, is typically foliated, and compositionally similar foliated intrusive rocks yielded similar ages to the south and east of Fort Irwin, in the Granite and Clipper Mountains. These data suggest that these ranges comprise remnants of a widespread deformed arc terrane. Compositionally similar, slightly 
younger Middle Jurassic calc-alkalic intrusive rocks of the Bullion sequence range in age from 167 to $164 \mathrm{Ma}$ and crop out south of the craton edge and south of the deformed arc terrane. LIL-enriched alkali-calcic intrusive rocks in the east Mojave were emplaced into this older deformed arc terrane as the pulse of magmatism began to wane. Waning magmatism is recorded in the Bristol Mountains sequence that yields Late Jurassic ages as young as $161 \mathrm{Ma}$ in the Bristol, Granite, Providence and Ship Mountains and in the Lava Hills.

Published ages for silicic extrusive rocks suggest Jurassic plutonism in the Mojave Desert was contemporaneous, at least at the m.y. time scale, with eruption of ignimbrites (Figures 5 and 13). Stratigraphic successions preserving the ignimbrite record of the Jurassic pulse are found in the east Mojave in the Providence and Cowhole Mountains, in the southeast Mojave in the Palen Mountains, and in the Sidewinder volcanic series in the west-central Mojave Desert. Explosive silicic volcanism commenced at approximately the same time (175 to $181 \mathrm{Ma})$ as our best estimate of the age of the oldest intrusive rocks in the Fort Irwin sequence and continued through Middle and Late Jurassic time coeval with emplacement of the Bullion and Bristol Mountains sequences. Rhyolitic and crystal-rich dacitic ignimbrites in the Sidewinder volcanic series show remarkable mineral and chemical similarities to nearby coeval plutons where mafic and felsic plutonic rocks are intimately intermingled (Fohey-Breting et al., 2010), suggesting that further exploration of the mafic plutonic record here will yield insights into the felsic plutonic-ignimbrite connection.

The geochronologic database allows insights into the interplay between tectonism and magmatism during the Jurassic pulse (Figure 13). The structural evolution of the 
Jurassic Mojave - Transverse Ranges continental arc was complex, with evidence for both shortening and extension (Busby-Spera, 1988; Schermer, 1993; Walker et al., 2002). Abundant caldera structural elements and incursions of eolian quartz-rich sand from the continental interior suggest that the arc was low-standing and perhaps characterized by both calderas and regional intra-arc graben (Busby-Spera, 1988; Schermer et al., 2002). Zircon ages for ignimbrites interlayered with or capping the eolian sandstones (Fackler-Adams et al., 1997; Schermer et al., 2002; Busby et al., 2002; Fohey-Breting et al., 2010; Stone et al., 2013) indicate these eolian sands are correlative with the Early Jurassic Navajo/Aztec and/or Middle Jurassic Carmel cratoninterior sandstones (Kowallis et al., 2001; Dickinson et al., 2010), suggesting that the low-standing arc persisted until early Middle Jurassic time, as late as $167 \mathrm{Ma}$. In contrast, Dunne et al. (1998) suggested the arc immediately north of the Mojave Desert was high-standing after $169 \mathrm{Ma}$, when a thick sequence of epiclastic strata in the upper Inyo Volcanic Complex was deposited by eastward-flowing streams. Bracketing ages of plutons indicate that shortening within the arc itself and in the proximal back-arc region accompanied the peak and waning stages of the Jurassic magma pulse in late Middle and Late Jurassic time, and may account for a regional transition in arc geomorphology. Shortening occurred by about $176 \mathrm{Ma}$ in the Clipper Mountains area (Howard et al., 1995), and shortening is bracketed between 172 and $162 \mathrm{Ma}$ in the Fort Irwin region (Schermer et al., 2001, and this study), 169 and $154 \mathrm{Ma}$ in the Cronese Hills (Walker et al., 1990) and 165 to $151 \mathrm{Ma}$ at Iron Mountain (Boettcher and Walker, 1993), the later three comprising the regional early to middle interval of the East Sierran thrust system of Dunne and Walker (2004). Taken together, the geochronologic and structural data 
permit an interpretation with minimal overlap in time between an Early to Middle Jurassic low-standing arc and Middle to Late Jurassic shortening within the arc basement as the magma pulse reached its maximum and waned. The early lowstanding arc probably experienced later crustal thickening via the combined effects of magmatism and intra-arc shortening along the southern extent of the East Sierran thrust system as the magma pulse developed. Alternatively, there may have been significant local to regional overlap between shortening and extension, which may reflect differential exhumation of an arc with vertically-partitioned strain. Hughes and Mahood (2008) summarized data from a range of modern arcs that suggest caldera magmatism is common in the upper crust of arcs that have high normal convergence rates and compressional upper plates. Additional (and more precise) ages for Jurassic ignimbrites and bracketing ages for deformation are needed to refine understanding of the interplay between shortening and extension at local to regional scales.

Geochemical data for whole rocks indicate regional similarities in pulse magma compositions north to south across the old craton edge, and secular variation in magma compositions as the pulse evolved. The Early to Middle Jurassic Fort Irwin and Bullion sequences are compositionally very similar high $\mathrm{K}$ calc-alkalic rock suites, and these contrast with the later, relatively LIL-enriched, shoshonitic, alkali-calcic Bristol Mountains sequence intruded in early Late Jurassic time. Regional relations and geochronology indicate that the younger alkali-calcic sequence is syn- to post-kinematic with respect to intra-arc and proximal retro-arc shortening along the East Sierran thrust system. Thus the transition from calc-alkalic to more alkalic magmatism was broadly 
synchronous with crustal thickening and the transition inferred above from a low- to high-standing arc edifice in the Mojave Desert region.

The broad synchroneity of topography, upper crust shortening, and the progression of magmatism suggests that crustal thickening beneath the arc played an important role in modulating the Jurassic magma pulse. The arc crust itself may have played a passive role, forcing deeper ponding of mantle-derived magmas and relatively high pressure fractionation, leading to a shoshonitic trend (Meen, 1987, 1990). In addition, intra-arc shortening may have actively induced magmatism through delivery of lower crust and lithospheric mantle to the subarc zone of magma generation without a significant time lag. These processes may have played complementary roles in modulating magma volume during the pulse, leading to enhanced lithophile element enrichment as the pulse evolved.

Trace element compositions of dated zircons reinforce and extend the regional and secular geochemical variations outlined above. Zircon trace element concentrations reflect melt compositions and are therefore useful for tracking melt evolution within an intrusive or extrusive sequence (e.g. Claiborne et al., 2010; Barth and Wooden, 2010). In this study, however, we group zircon data to examine arc-wide variations and regional and secular variations in average melt composition between the three Jurassic sequences. Taken together, magmatic zircons from the three Mojave - Transverse Ranges sequences have Th/U mostly $\sim 0.5-1.3$ and $\mathrm{Yb} / \mathrm{Gd}$ of $\sim 10$ to 30 , extensively overlapping with the compositional range of Jurassic zircons from the Sierra Nevada and southeast Mojave - Colorado River region (Fohey-Breting et al., 2010; Tosdal and Wooden, 2015; Figure 14). These gross geochemical similarities and the presence of 
distinctive, similarly high Th/U and low to moderate $\mathrm{Yb} / \mathrm{Gd}$ in retro-arc detrital zircons of similar age (Barth et al., 2013) allow us to infer that these compositions are characteristic of the Jurassic California arc along its entire length.

This high $\mathrm{Th} / \mathrm{U}$, moderate $\mathrm{Yb} / \mathrm{Gd}$ zircon geochemical signature is modified within the Mojave - Transverse Ranges arc segment based on the local crust-mantle system, because of the juxtaposition of young lithosphere with the edge of an older cratonic lithospheric province characterized by long-term high Th/U (Wooden and Miller, 1990; Wooden and DeWitt, 1991; Miller et al., 1995). In the two otherwise-similar Early to Middle Jurassic calc-alkalic sequences, zircons with higher Th/U $(1-2)$ are found in the Bullion sequence intruded inboard of the old craton edge (Figures 10 and 11). This high Th/U signal of old lithospheric input is amplified in the alkali-calcic Bristol Mountains sequence, where all measured zircons have $T h / U>1$. The very high $T h / \cup$ in these young Bristol Mountains sequence zircons is accompanied by markedly higher $\mathrm{Ce} / \mathrm{Yb}$ and lower $\mathrm{U} / \mathrm{Yb}$, implying melts generated in this later stage of the magma pulse were comparatively U-poor and light REE enriched. We hypothesize that the high $\mathrm{Th} / \mathrm{U}$, coupled with $U$ depletion and light REE enrichment, are a consistent set of observations indicating progressive regional crustal thickening and relatively greater involvement of old cratonic lithosphere in magmatism as the pulse evolved. These observations suggest that zircon geochemistry has preserved regional and secular variations in melt compositions reflecting the inherited structure and the evolution of the arc framework during the magma pulse.

\section{ACKNOWLEDGMENTS}


Research supported by the U.S. Geological Survey, the U.S. National Science Foundation (EAR0711119 and 1348059 to APB and 1347954 to CEJ), and the Blaustein Fund at Stanford University. APB thanks the faculty and staff at Stanford University for their hospitality. We thank J. Wright and R. Tosdal for sharing samples, S. Shaw for sharing XRF analyses, Brad Ito for expert technical support with SIMS, and C.

Allen, S. de Silva, E. Miller, N. Riggs, P. Stone and J.D. Walker for helpful discussions.

E. Christiansen, C. Miller and P. Stone provided helpful and constructive manuscript reviews.

\section{REFERENCES CITED}

Anderson, J.L., Barth, A.P., Wooden, J.L., and Mazdab, F., 2008, Thermometers and thermobarometers in granitic systems, in Putirka, K.D., and Tepley, F.J., eds., Minerals, Inclusions and Volcanic Processes: Mineralogical Society of America Reviews in Mineralogy 69, p. 121-142.

Arculus, R.J., 2003, Use and abuse of the terms calcalkaline and calcalkalic: Journal of Petrology, v. 44, p. 929-935.

Baedecker, P.A., and McKown, D.M., 1987, Instrumental neutron activation analysis of geochemical materials, in Baedecker, P.A., ed., Methods for geochemical analysis: U.S. Geological Survey Bulletin 1770, p. H1-H14.

Barth, A.P., and Wooden, J.L., 2006, Timing of magmatism following initial convergence at a passive margin, southwestern U.S. Cordillera, and ages of lower crustal magma sources: Journal of Geology, v. 114, p. 231-245.

Barth, A.P., and Wooden, J.L., 2010, Coupled elemental and isotopic analyses of polygenetic zircons from granitic rocks by ion microprobe, with implications for melt 
evolution and the sources of granitic magmas: Chemical Geology, v. 277, p. 149159.

Barth, A.P., Wooden, J.L., Jacobson, C.E., and Probst, K., 2004, U-Pb geochronology and geochemistry of the McCoy Mountains Formation, southeastern California: A Cretaceous retroarc foreland basin: Geological Society of America Bulletin, v. 116, p. $142-153$.

Barth, A.P., Wooden, J.L., Howard, K.A., and Richards, J.L., 2008, Late Jurassic plutonism in the southwest U.S. Cordillera, in Wright, J.E., and Shervais, J.W., eds., Ophiolites, Arcs, and Batholiths: A Tribute to Cliff Hopson: Geological Society of America Special Paper 438, p. 379-396.

Barth, A.P., Walker, J.D., Wooden, J.L., Riggs, N.R., and Schweickert, R.A., 2011, Birth of the Sierra Nevada magmatic arc: Early Mesozoic plutonism and volcanism in the east central Sierra Nevada of California: Geosphere, v. 7, p. 877-897, doi: 10.1130/GES00661.1.

Barth, A.P., Feilen, A.D.G., Yager, S.L., Douglas, S.R., Wooden, J.L., Riggs, N.R., and Walker, J.D., 2012, Petrogenetic connections between ash-flow tuffs and a granodioritic to granitic intrusive suite in the Sierra Nevada arc, California: Geosphere, v. 8, p. 250-264, doi:10.1130/GES00737.1.

Barth, A.P., Wooden, J.L., Jacobson, C.E., and Economos, R.C., 2013, Detrital zircon as a proxy for tracking the magmatic arc system: the California arc example: Geology, v. 41, p. 223-226, doi:10.1130/G33619.1.

Black, L.P., Kamo, S.L., Allen, C.M., Davis, D.W., Aleinikoff, J.N., Valley, J.W., Mundil, R.M., Campbell, I.H., Korsch, R.J., Williams, I.S., and Foudoulis, C., 2004, 
Improved ${ }^{206} \mathrm{~Pb} / 238 \mathrm{U}$ microprobe geochronology by the monitoring of a traceelement-related matrix effect: SHRIMP, ID-TIMS, ELA-ICP-MS, and oxygen isotope documentation for a series of zircon standards: Chemical Geology, v. 205, p. $115-140$.

Boettcher, S.S., and Walker, J.D., 1993, Geologic evolution of Iron Mountain, central Mojave Desert, California: Tectonics, v. 12, p. 372-386.

Busby, C.J., Schermer, E.R., and Mattinson, J.M., 2002, Extensional arc setting and ages of middle Jurassic eolianites, Cowhole Mountains (eastern Mojave Desert block, California), in Glazner, A.F., Walker, J.D., and Bartley, J.M., eds., Geologic Evolution of the Mojave Desert and Southwestern Basin and Range: Geological Society of America Memoir 195, p. 79-91.

Busby-Spera, C.J., 1988, Speculative tectonic model for the early Mesozoic arc of the southwest Cordilleran United States: Geology, v. 16, p. 1121-1125.

Calzia, J.P., 1982, Geology of granodiorite in the Coxcomb Mountains, southeastern California, in Frost, E.G. and Martin, D.L, eds., Mesozoic-Cenozoic tectonic evolution of the Colorado River region, California, Arizona, and Nevada: San Diego, Cordilleran Publishers, p. 173-181.

Carl, B.S., and Glazner, A.F., 2002, Extent and significance of the Independence dike swarm, eastern California, in Glazner, A.F., Walker, J.D., and Bartley, J.M., eds., Geologic Evolution of the Mojave Desert and Southwestern Basin and Range: Geological Society of America Memoir 195, p. 117-130.

Christiansen, E.H., Kowallis, B.J., Dorais, M.J., Hart, G.L., Mills, C.N., Pickard, M., and Parks, E., 2015, The record of volcanism in the Brushy Basin Member of the 
Morrison Formation: Implications for the Late Jurassic of western North America, in Anderson, T.H., Didenko, A.N., Johnson, C.L., Khanchuk, A.I., and MacDonald, J.H., eds., Late Jurassic Margin of Laurasia - A Record of Faulting Accommodating Plate Rotation: Geological Society of America Special Paper 513, doi:10.1130/2015.2513(11).

Claiborne, L.L., Miller, C.F., and Wooden, J.L., 2010, Trace element composition of igneous zircon: A thermal and compositional record of the accumulation and evolution of a large silicic batholith, Spirit Mountain, Nevada: Contributions to Mineralogy and Petrology, v. 21, p. 511-531, doi:10.1007/s00410-010-0491-5. de Silva, S.L., 1989, Altiplano - Puna volcanic complex of the central Andes: Geology, v. 17, p. $1102-1106$.

de Silva, S.L., and Gosnold, W.D., 2007, Episodic construction of batholiths: Insights from the spatiotemporal development of an ignimbrite flare-up: Journal of Volcanology and Geothermal Research, v. 167, p. 320-335.

de Silva, S.L., Riggs, N.R., and Barth, A.P., 2015, Quickening the pulse: Fractal tempos in continental arc magmatism: Elements, v. 11, p. 113-118.

Dickinson, W.R., Stair, K.N., Gehrels, G.E., Peters, L., Kowallis, B.J., Blakey, R.C., Amar, J.R., and Greenhalgh, B.W., 2010, U-Pb and ${ }^{40} \mathrm{Ar} /{ }^{39} \mathrm{Ar}$ ages for a tephra lens in the Middle Jurassic Page Sandstone: First direct isotopic dating of a Mesozoic eolianite on the Colorado Plateau: Journal of Geology, v. 118, p. 215-221. Dickinson, W.R., and Gehrels, G.E., 2010, Insights into North American paleogeography and paleotectonics from $\mathrm{U}-\mathrm{Pb}$ ages of detrital zircons in Mesozoic 
strata of the Colorado Plateau, USA: International Journal of Earth Sciences, v. 99, p. $1247-1265$.

Ducea, M.N., and Barton, M.D., 2007, Igniting flare-up events in Cordilleran arcs: Geology, v. 35, p. 1047-1050.

Dunne, G.C., and Walker, J.D., 2004, Structure and evolution of the East Sierran thrust system, east central California: Tectonics, v. 23, TC4012, 23 p.

Dunne, G.C., Garvey, T.P., Oborne, M., Schneidereit, D., Fritsche, A.E., and Walker, J.D., 1998, Geology of the Inyo Mountains Volcanic Complex: Implications for Jurassic paleogeography of the Sierran magmatic arc in eastern California: Geological Society of America Bulletin, v. 110, p. 1376-1397.

Economos, R.C., Barth, A.P., and Wooden, J.L., 2010, Southern US Cordillera premagmatic zircons: Sounding a Cordilleran source region: Geochimica et Cosmochimica Acta, v. 74, p. A258.

Fackler-Adams, B.N., Busby, C.J., and Mattinson, J.M., 1997, Jurassic magmatism and sedimentation in the Palen Mountains, southeastern California: Implications for regional tectonics on the Mesozoic continental arc: Geological Society of America Bulletin, v. 109, p. 1464-1484.

Fohey-Breting, N.K., Barth, A.P., Wooden, J.L., Mazdab, F.K., Carter, C.A., and Schermer, E.R., 2010, Relationship of voluminous ignimbrites to continental arc plutons: Petrology of Jurassic ignimbrites and contemporaneous plutons in southern California: Journal of Volcanology and Geothermal Research, v. 189, p. $1-11$. 
Foster, D.A., Harrison, T.M., Miller, C.F., and Howard, K.A., 1990, The ${ }^{40} \mathrm{Ar} /{ }^{39} \mathrm{Ar}$ thermochronology of the eastern Mojave Desert, California, and adjacent western Arizona with implications for the evolution of metamorphic core complexes: Journal of Geophysical Research, v. 95, p. 20,005-20,024.

Foster, D.A., Miller, C.F., Harrison, T.M., and Hoisch, T.D., 1992, Timing and character of metamorphism and tectonism in the Old Woman Mountains area, California: Evidence from ${ }^{40} \mathrm{Ar} /{ }^{39} \mathrm{Ar}$ thermochronology and thermobarometry: Geological Society of America Bulletin, v. 104, p. 176-191.

Fox, L.K., and Miller, D.M., 1990, Jurassic granitoids and related rocks of the southern Bristol Mountains, southern Providence Mountains, and Colton Hills, Mojave Desert, California, in Anderson, J.L., ed., The Nature and Origin of Cordilleran Magmatism: Geological Society of America Memoir 174, p. 111-132.

Gerber, M.E., Miller, C.F., and Wooden, J.L., 1995, Plutonism at the interior margin of the Jurassic magmatic arc, Mojave Desert California, in Miller, D.M., and Busby, C. eds., Jurassic Magmatism and Tectonics of the North American Cordillera: Geological Society of America Special Paper 299, p. 351-374.

Glazner, A.F., Bartley, J.M., and Carl, B.S., 1999, Oblique opening and noncoaxial emplacement of the Jurassic Independence dike swarm: Journal of Structural Geology, v. 21, p. 1275-1283.

Haxel, G.B., and Miller, D.M., 2007, Mesozoic rocks, in Theodore, T.G., ed., Geology and Mineral Resources of the East Mojave National Scenic Area, San Bernardino County, California: U.S. Geological Survey Bulletin 2160, p. 59-66. 
Howard, K.A., 2002, Geologic map of the Sheep Hole Mountains 30 × 60 quadrangle, San Bernardino and Riverside Counties, California: U.S. Geological Survey Miscellaneous Field Studies Map MF2344, scale 1:100,000.

Howard, K.A., Kilburn, J.E., Simpson, R.W., Fitzgibbon, T.T., Detra, D.E., Raines G.L., and Sabine, C., 1987, Mineral resources of the Bristol/Granite Mountains Wilderness Study Area, San Bernardino County, California: US Geological Survey Bulletin 1712-C, 18 pp.

Howard, K.A., McCaffrey, K.J.W., Wooden, J.L., Foster, D.A., and Shaw, S.E., 1995, Jurassic thrusting of Precambrian basement over Paleozoic cover in the Clipper Mountains, southeastern California, in Miller, D.M., and Busby, C., eds., Jurassic Magmatism and Tectonics of the North American Cordillera: Geological Society of America Special Paper 299, p. 375-392.

Howard, K.A., Bacheller, J., Fitzgibbon, T.T., Powell, R.E., and Allen, C.M., 2013a, Geologic map of the Valley Mountain 15' quadrangle, San Bernardino and Riverside Counties, California: U.S. Geological Survey Geologic Quadrangle Map GQ-1767, scale 1:62,500.

Howard, K.A., Jagiello, K.J., Fitzgibbon, T.T., and Allen, B.E., 2013b, Geologic map of the Lead Mountain 15' quadrangle, San Bernardino County, California: U.S. Geological Survey Geologic Quadrangle Map GQ-1766, scale 1:62,500. Hughes, G.R., and Mahood, G.A., 2008, Tectonic controls on the nature of large silicic calderas in volcanic arcs: Geology, v. 36, p. 627-630.

Jacobson, C.E., Grove, M., Pedrick, J.N., Barth, A.P., Marsaglia, K.M., Gehrels, G.E., and Nourse, J.A., 2011, Late Cretaceous-early Cenozoic tectonic evolution of the 
southern California margin inferred from provenance of trench and forearc sediments: Geological Society of America Bulletin, v. 123, p. 485-506

John, B.E., 1981, Reconnaissance study of Mesozoic plutonic rocks in the Mojave Desert region, in Howard, K.A., Carr, M.D., and Miller, D.M, eds., Tectonic framework of the Mojave and Sonoran Deserts: U.S. Geological Survey Open-File Report 81-503, p. 48-50.

Kowallis, B.J., Christiansen, E.H., Deino, A.L., Zhang, C., and Everett, B.H., 2001, The record of Middle Jurassic volcanism in the Carmel and Temple Cap Formations of southwestern Utah: Geological Society of America Bulletin, v. 113, p. 373-387.

Ludwig, K.R., 2001, Squid 1.02 a user's manual: Berkeley Geochronology Center Special Publication No. 2, 19 p.

Ludwig, K.R., 2012, A geochronologic toolkit for Microsoft Excel: Berkeley Geochronology Center Special Publication No. 5, 75 p.

Martin, M.W., and Walker, J.D., 1992, Extending the western North American Proterozoic and Paleozoic continental crust through the Mojave Desert: Geology, v. 20, p. $753-756$.

Mayo, D.P., Anderson, J.L., and Wooden, J.L., 1998, Isotopic constraints on the petrogenesis of Jurassic plutons, southeastern California: International Geology Review, v. 40, p. 421-442.

Meen, J.K., 1987, Formation of shoshonites from calcalkaline basalt magmas: geochemical and experimental constraints from the type locality: Contributions to Mineralogy and Petrology, v. 97, p. 333-351. 
Meen, J.K., 1990, Elevation of potassium content of basaltic magma by fractional crystallization: the effect of pressure: Contributions to Mineralogy and Petrology, v. 104, p. 309-331.

Miller, C.F., Howard, K.A., and Hoisch, T.D., 1982, Mesozoic thrusting, metamorphism and plutonism, Old Woman - Piute Range, southeastern California, in Frost, E.G., and Martin, D.L., eds., Mesozoic-Cenozoic tectonic evolution of the Colorado River region, California-Arizona-Nevada: San Diego, Cordilleran Publishers, p. 561-581.

Miller, J.S., and Glazner, A.F., 1995, Jurassic plutonism and crustal evolution in the central Mojave Desert, California: Contributions to Mineralogy and Petrology, v. 118, p. 379-395.

Miller, J.S., Glazner, A.F., Walker, J.D., and Martin, M.W., 1995, Geochronologic and isotopic evidence for Triassic-Jurassic emplacement of the eugeoclinal allochthon in the Mojave Desert region, California: Geological Society of America Bulletin, v. 107, p. 1441-1457.

Miyashiro, A., 1974, Volcanic rock series in island arcs and active continental margins: American Journal of Science, v. 274, p. 321-355.

Peacock, M.A., 1931, Classification of igneous rock series: Journal of Geology, v. 39, p. 54-67.

Reis, J., Jacobson, C.E., Barth, A.P., Pedrick, J.N., Haxel, G., and Harding, C., 2008, Age, provenance, and potential correlations of the rocks of Slumgullion, Castle Dome Mountains, southwest Arizona: Geological Society of America Abstracts with Programs, v. 40, p. 156. 
Saleeby, J., 2011, Geochemical mapping of the Kings-Kaweah ophiolite belt, California - Evidence for progressive mélange formation in a large offset transformsubduction initiation environment: Geological Society of America Special Paper 480, p. 31-73.

Saleeby, J.B., Kistler, R.W., Longiaru, S., Moore, J.G., and Nokleberg, W.J., 1990, Middle Cretaceous silicic metavolcanic rocks in the Kings Canyon area, central Sierra Nevada, California, in Anderson, J.L., ed., The Nature and Origin of Cordilleran Magmatism: Geological Society of America Memoir 174, p. 251-270.

Saleeby, J.B., and Busby-Spera, C., 1992, Early Mesozoic tectonic evolution of the western U.S. Cordillera, in Burchfiel, B.C., Lipman, P.W., and Zoback, M.L., eds., The Cordilleran Orogen: Conterminous U.S.: Geological Society of America, Geology of North America, v. G3, p. 107-168.

Schermer, E.R., 1993, Mesozoic structural evolution of the west-central Mojave Desert in Dunne, G., and MacDougall, K.A., eds., Mesozoic Paleogeography of the Western United States, 2: SEPM Paleogeography Symposium, p. 307-322. Schermer, E.R., and Busby, C.J., 1994, Jurassic magmatism in the central Mojave Desert: Implications for arc paleogeography and preservation of continental volcanic sequences: Geological Society of America Bulletin, v. 106, p. 767-790.

Schermer, E.R., Stephens, K.A., and Walker, J.D., 2001, Paleogeographic and tectonic implications of the geology of the Tiefort Mountains, northern Mojave Desert: Geological Society of America Bulletin, v. 113, p. 920-938.

Schermer, E., Busby, C.J., and Mattinson, J.M., 2002, Paleogeographic and tectonic implications of Jurassic sedimentary and volcanic sequences in the central Mojave 
block, in Glazner, A.F., Walker, J.D., and Bartley, J.M., eds., Geologic evolution of the Mojave Desert and southwestern Basin and Range: Geological Society of America Memoir 195, p. 93-115.

Stewart, J.H., and Poole, F.G., 1975, Extension of the Cordilleran miogeosynclinal belt to the San Andreas fault, southern California: Geological Society of America Bulletin, v. 86, p. 205-212.

Stone, P., and Stevens, C.H., 1988, Pennsylvanian and Early Permian paleogeography of east-central California: Implications for the shape of the continental margin and the timing of continental truncation: Geology, v. 16, p. 330-333.

Stone, P., Barth, A.P., Wooden, J.L., Fohey-Breting, N.K., Vazquez, J.A., and Priest, S.S., 2013, Geochronologic and geochemical data from Mesozoic rocks in the Black Mountain area northeast of Victorville, San Bernardino County, California: U.S. Geological Survey Open-File Report 2013-1146, 31 p.

Todd, V.R., Shaw, S.E., and Hammarstrom, J.M., 2003, Cretaceous plutons of the Peninsular Ranges batholith, San Diego and westernmost Imperial counties, California: Intrusion across a Late Jurassic continental margin, in Johnson, S.E. et al., eds., Tectonic Evolution of Northwestern Mexico and the Southwestern USA: Geological Society of America Special Paper 374, p. 185-236.

Tosdal, R.M., and Wooden, J.L., 2015, Construction of the Jurassic magmatic arc, southeast California and southwest Arizona, in Anderson, T.H., Didenko, A.N., Johnson, C.L., Khanchuk, A.I., and MacDonald, J.H., eds., Late Jurassic Margin of the Laurasia - A Record of Faulting Accommodating Plate Rotation: Geological Society of America Special Paper 513, doi:10.1130/2015.2513(04). 
Tosdal, R.M., Haxel, G.B., and Wright, J.E., 1989, Jurassic geology of the Sonoran Desert region, southern Arizona, southeast California, and northernmost Sonora: Construction of a continental margin magmatic arc: Arizona Geological Society Digest, v. 17, p. 397-434.

Walker, J.D., Martin, M.W., Bartley, J.M., and Coleman, D.S., 1990, Timing and kinematics of deformation in the Cronese Hills, California, and implications for Mesozoic structure of the southwestern Cordillera: Geology, v. 18, p. 554-557. Walker, J.D., Martin, M.W., and Glazner, A.F., 2002, Late Paleozoic to Mesozoic development of the Mojave Desert and environs, California, in Glazner, A.F., Walker, J.D., and Bartley, J.M., eds., Geologic Evolution of the Mojave Desert and Southwestern Basin and Range: Geological Society of America Memoir 195, p. 118.

Walker, J.D., Geissman, J.W., Bowring, S.A., and Babcock, L.E., 2012, Geologic Time Scale v. 4.0: Geological Society of America, doi: 10.1130/2012.CTS004R3C.

Whalen, J.B., Currie, K.L., and Chappell, B.W., 1987, A-type granites: geochemical characteristics, discrimination and petrogenesis: Contributions to Mineralogy and Petrology, v. 95, p. 407-419.

Wooden, J.L., and Miller, D.M., 1990, Chronologic and isotopic framework for Early Proterozoic crustal evolution in the eastern Mojave Desert region, SE California: Journal of Geophysical Research, v. 95, p. 20133-20146.

Wooden, J.L., and DeWitt, E., 1991, Isotopic evidence for the boundary between the Early Proterozoic Mojave and central Arizona crustal provinces in western Arizona, 
in Karlstrom, K.E., ed. , Proterozoic Geology and Ore Deposits of Arizona: Arizona Geological Society Digest, v. 19, p. 27-50.

Young, E.D., Wooden, J.L., Shieh, Y.-N., and Farber, D., 1992, Geochemical evolution of Jurassic diorites from the Bristol Lake region, California, and the role of assimilation: Contributions to Mineralogy and Petrology, v. 110, p. 68-86.

\section{FIGURE CAPTIONS}

Figure 1. Regional map of Jurassic intrusive sequences in the Mojave Desert and Transverse Ranges of southern California. Major structural features are MH - Paleozoic miogeocline hinge approximating the edge of old cratonic lithosphere, ESTS - Jurassic East Sierra thrust system (Walker et al., 1990, 2002), and SAF - San Andreas fault. Figure 2. Summary of regional age-frequency relationships in the Jurassic Cordilleran forearc, arc, retroarc and continental interior. Detrital zircon ages in Cretaceous to Eocene forearc basin sediments are from Jacobson et al. (2011 and unpublished data). Ages of arc igneous rocks in the Mojave Desert and Transverse Ranges from Davis et al. (1994), Fackler-Adams et al. (1997), Mayo et al. (1998), Schermer et al. (2002), Barth et al. (2004, 2008), Fohey-Breting et al. (2010), and Stone et al. (2013). Detrital zircon ages in Jurassic (?) - Cretaceous retroarc basin sediments are from Barth et al. (2004) and Reis et al. (2008). Stratigraphy of ashes on the Colorado Plateau is from Kowallis et al. (2001), Dickinson et al. (2010) and Christiansen et al. (2015). Boundaries of Jurassic epochs are based on the time scale of Walker et al. (2012).

Figure 3. Tera-Wasserburg Concordia diagrams and weighted mean ${ }^{206} \mathrm{~Pb}^{\star} / 238 \mathrm{U}$ ages for zircons from rock units of the Fort Irwin sequence. All measured zircons are plotted 
on Concordia diagrams at left; zircon analyses plotted with unshaded symbols were excluded from calculation of weighted mean crystallization age shown at right. See text for discussion. MSWD = mean square of weighted deviates.

Figure 4. Tera-Wasserburg Concordia diagrams and weighted mean ${ }^{206} \mathrm{~Pb}^{\star / 238} \mathrm{U}$ ages for zircons from samples of the quartz monzonite of Bull Canyon in the Granite Mountains, granodiorite from the Goldhammer pluton in the Clipper Mountains, and granodiorite from Cave Mountain. All measured zircons are plotted on Concordia diagrams at left; zircon analyses plotted with unshaded symbols were excluded from calculation of weighted mean crystallization age shown at right. See text for discussion. Figure 5. Geochronologic summary for Jurassic igneous rocks in the Mojave Desert. Left panel summarizes SIMS ages (with analytical uncertainties) for Early to Middle Jurassic intrusive rocks of the Fort Irwin sequence (and Goldhammer pluton), Bullion sequence, and the Bristol Mountains sequence. The grey band is the total age range of thirteen intrusive rocks in the Late Jurassic arc (Barth et al., 2008). Right panel compares available U-Pb zircon ages for hypabyssal and volcanic rocks; light grey bars are ages of ash-flow tuffs, and dark grey bars are ages of lavas, hypabyssal rocks and dikes. Data sources: Cowhole Mountains TIMS (Busby et al., 2002), Palen Mountains TIMS and SIMS ages (Fackler-Adams et al., 1997; Barth et al., 2004), Sidewinder Volcanic Series SIMS ages (Fohey-Breting et al., 2010; Stone et al., 2013), Holcomb Valley SIMS ages (Barth et al., 2008). The grey band is the total age range of Independence dikes compiled by Glazner et al. (1999) and Carl and Glazner (2002). Boundaries of Jurassic epochs are based on the time scale of Walker et al. (2012). 
Figure 6. Tera-Wasserburg Concordia diagrams and weighted mean ${ }^{206} \mathrm{~Pb}^{\star / 238} \mathrm{U}$ ages for zircons from samples of the Bristol Mountains sequence. All measured zircons are plotted on Concordia diagrams at left; zircon analyses plotted with unshaded symbols were excluded from calculation of weighted mean crystallization age shown at right. See text for discussion.

Figure 7. Tera-Wasserburg Concordia diagrams and weighted mean ${ }^{206} \mathrm{~Pb}^{\star / 238} \mathrm{U}$ ages for zircons from samples of the Bullion sequence. All measured zircons are plotted on Concordia diagrams at left; zircon analyses plotted with unshaded symbols were excluded from calculation of weighted mean crystallization age shown at right. See text for discussion.

Figure 8. Whole rock potassium contents and iron enrichment as a function of silica content of Jurassic plutonic rocks. Additional data for Bristol Mountains sequence from Fox and Miller (1990) and Gerber et al. (1995), and for Bullion sequence from Mayo et al. (1998).

Figure 9. Whole rock zirconium contents and light REE enrichment as a function of silica content of Jurassic plutonic rocks. Additional data sources as in Figure 8. Figure 10. $U$ and Th concentrations in magmatic zircons. Zircons in the Fort Irwin sequence are uniformly low in $\mathrm{Th} / \mathrm{U}(0.5$ to 1$)$, zircons from the Bullion sequence range have low to intermediate $T h / \cup$, and zircons in the Bristol Mountains sequence have lowest average concentrations and uniformly high $\mathrm{Th} / \mathrm{U} \cong 1$ to 3 . Additional data for Bullion sequence from Fohey-Breting et al. (2010). 
Figure 11. Th/U vs. Yb/Gd and Hf concentrations in Jurassic magmatic zircons. Light shaded diamonds are comparative data for Jurassic magmatic zircons from the Sierra Nevada batholith (Wooden and Barth, unpub. data).

Figure 12. $\mathrm{U} / \mathrm{Yb}$ and rare earth element fractionation in Jurassic magmatic zircons. Note that zircons from the alkali-calcic Bristol Mountains sequence are relatively heavy REE depleted and are uniformly low in $\mathrm{U} / \mathrm{Yb}$ compared to zircons in the Fort Irwin and Bullion sequences.

Figure 13. Magmatic zircon age record of the Jurassic magma pulse in the Mojave Desert, Transverse Ranges and northern Sonoran Desert. Ages of individual igneous rocks (with uncertainties) from Fackler-Adams et al. (1997), Busby et al. (2002), Schermer et al. (2002), Barth et al. (2004, 2008), Fohey-Breting et al. (2010), Stone et al. (2013), Tosdal and Wooden (2015) and this study. Dashed and shaded boxes represent time ranges of inferred intra-arc extension at Sidewinder Mountain - Stoddard Ridge and in the Palen and Cowhole Mountains (Tosdal et al., 1989; Fackler-Adams et al., 1997; Schermer et al., 2002; Busby et al., 2002). Solid and shaded boxes represent time ranges of shortening in the Fort Irwin region and in the Cronese Hills (Walker et al., 1990; Schermer et al., 2001; Walker et al., 2002; this study).

Figure 14. Trace element geochemistry of magmatic zircon in the Jurassic California arc in the Mojave Desert (this study), Colorado River (Tosdal and Wooden, 2015), and Sierra Nevada (Wooden and Barth, unpub. data), illustrating the high Th/U and moderate $\mathrm{Yb} / \mathrm{Gd}$ characteristic of Jurassic zircons from all three arc segments. 